\title{
LOGIKA FUZZY SUGENO UNTUK PENGAMBILAN KEPUTUSAN DALAM PENJADWALAN DAN PENGINGAT SERVICE SEPEDA MOTOR
}

\author{
Ariesta Dwi Saputri ${ }^{\# 1}$, Rima Dias Ramadhani ${ }^{\# 2}$, Rifki Adhitama ${ }^{\# 3}$ \\ \# Institut Telknologi Telkom Purwokerto \\ Jl. D.I Panjaitan No. 128 Purwokerto 53147 \\ ${ }^{1}$ titatha9@gmail.com, ${ }^{2}$ rima@ittelkom-pwt.ac.id, ${ }^{3}$ rifki@ittelkom-pwt.ac.id
}

Accepted on 08-08-2019

\begin{abstract}
Data pengguna sepeda motor tahun 2016 berdasarkan Badan Pusat Statistik terdapat 105.150.082 pengguna di Indonesia. Angka ini adalah angka yang terbanyak dari semua total kendaraan. Menurut katadata.co.id, terdapat 98.000 kali kecelakan yang terjadi pada tahun 2017. Hal ini didominasi oleh kendaraan khususnya sepeda motor. Kecelakan yang ditimbulkan disebabkan oleh kelalaian pengguna sepeda motor dalam merawat motornya tersebut.Upaya dalam mengantisipasi terjadinya kecelakaan salah satunya adalah melakukan pengecekan kendaraan bermotor secara rutin. Menurut buku panduan sepeda motor, bahwa setiap kali motor yang digunakan wajib untuk melakukan pengecekan minimal 3 bulan sekali agar motor tetap pada performa utamanya. Metode yang digunakan untuk pengambilan keputusan dalam penjadwalan dan pengingat menggunakan metode fuzzy sugeno. Fuzzy merupakan suatu cara untuk memetakan suatu ruang input ke dalam suatu ruang output. Solusi yang ditawarkan pada penelitian ini akan aplikasi mobile yang dikhususkan untuk pengguna sepeda motor dalam melakukan perawatan rutin sebagai penjadwalan dan pengingat. Hasil yang didapatkan Berdasarkan pengujian manual dan pengujian melalui system yakni 16 siap service dan 14 tidak siap service. Presentase keakuratan system dengan perhitungan manual 100\% sama dengan perhitngan system. Prensentasi pengaruh terhadap perawatan motor adalah $88.27 \%$ setuju terhadap pembuatan aplikasi ini untuk perawatan motor terhadap kecelakaan motor.
\end{abstract}

Keywords: Application, Fuzzy Sugeno, Mobile, Motor Life

\section{INTRODUCTION}

D ata pengguna sepeda motor tahun 2016 berdasarkan Badan Pusat Statistik terdapat 105.150.082 pengguna di Indonesia [1]. Angka ini adalah angka yang terbanyak dari semua total kendaraan.Menurut katadata.co.id [2], terdapat 98.000 kali kecelakan yang terjadi pada tahun 2017. Hal ini didominasi oleh kendaraan khususnya sepeda motor. Kecelakan yang ditimbulkan disebabkan oleh kelalaian pengguna sepeda motor dalam merawat motornya tersebut. Salah satunya adalah ban botak yang menyebabkan terjadinya kecelakaan. Upaya dalam mengantisipasi terjadinya kecelakaan salah satunya adalah melakukan pengecekan kendaraan bermotor secara rutin. Menurut buku panduan sepeda motor, bahwa setiap kali motor yang digunakan wajib untuk melakukan pengecekan minimal 3 bulan sekali agar motor tetap pada performa utamanya. 
Pada bidang ilmu informatika terdapat metode atau algoritma yang berfungsi untuk pengambilan keputusan. Metode yang digunakan untuk pengambilan keputusan dalam penjadwalan dan pengingat menggunakan metode fuzzy. Fuzzy merupakan suatu cara untuk memetakan suatu ruang input ke dalam suatu ruang output [3]. Terdapat 3 macam metode fuzzy yaitu tsukamoto, mamdani, dan sugeno. Ketiga metode tersebut memiliki kelebihan dan kekurangan masing-masing. Pada Fuzzy tsukamoto, setiap aturan direpresentasikan menggunakan himpunan-himpunan fuzzy, dengan fungsi keanggotaan yang monoton [4]. Metode defuzzifikasi yang digunakan dalam metode Tsukamoto adalah metode defuzzifikasi rata-rata terpusat (Center Average Defuzzyfier). Pada Fuzzy Mamdani, Saat melakukan evaluasi aturan dalam mesin inferensi, metode Mamdani menggunakan fungsi MIN dankomposisiantar-rule menggunakan fungsi MAX untuk menghasilkan himpunan fuzzy baru [5]. Sedangkan penalaran dengan Metode Sugeno hampir sama dengan penalaran Mamdani, hanya saja output (konsekuen) system tidak berupa himpunan fuzzy melainkan berupa konstanta atau persamaan linier. Metode ini diperkenalkan oleh Takagi-Sugeno Kang pada tahun 1985. Sistem fuzzy Sugeno memperbaiki kelemahan yang dimiliki oleh sistem fuzzy murni untuk menambah suatu perhitungan matematika sederhana sebagai bagian THEN. Pada perubahan ini, system fuzzy memiliki suatu nilai rata-rata tertimbang (Weighted Average Values) di dalam bagian aturan fuzzy IF-THEN. Sistem fuzzy Sugeno juga memiliki kelemahan terutama pada bagian THEN, yaitu dengan adanya perhitungan matematika sehingga tidak dapat menyediakan kerangka alami untuk representasikan pengetahuan manusia dengan sebenarnya.

Solusi yang ditawarkan pada penelitian ini akan diusukan aplikasi mobile yang dikhususkan untuk pengguna sepeda motor dalam melakaukan perawatan rutin sebagai penjadwalan dan pengingat. (penerapan sugeno dalam mengambil keputusan. Diceritakan secara general penggunaan fuzzy di aplikasi pengambil keputusan).Diharapkan dengan adanya aplikasi ini untuk mempermudah pengguna sebagai pengingat dalam perawatan motor agar terhindar dari kecelakaan tersebut.

\section{LITERATURE REVIEW}

Dalam penelitian ini telah melakukan penelusuran terhadap penelitian sebelumnya yang sekiranya berkaitan atau serupa dengan pengimplemetasian sebuah logika Fuzzy Sugeno pada aplikasi pendukung keputusan. Beberapa penelitian tersebut antara lain:

1. Muhammad Rofiq (2013) Perancangan Manajemen Bandwidth Internet Menggunakan Metode Fuzzy Sugeno [8] cepat dan ada yang lambat bahkan tidak dapat akses sama sekali. Dalam perancangan manajemen bandwidth ini dikembangkan dengan menggunakan metode fuzzy sugeno. Tujuan yang dicapai adalah untuk mengoptimal pemakaian akses internet. Input sistem berupa akses internet saat itu (real time).

2. Dina Hervita (2017) Sistem Monitoring Level Air Radiator Kendaraan Dengan Metode Fuzzy[9]. Pada penelitian ini data dari sensor ultra sonic akan dikirim ke mikrokontroller dengan logika fuzzy. Pemeilik kendaraan dapat mendapatkan informasi melalui modul wifi Wemos ESP8266 sehingga keadaan bagian dalam pada kendaraan dapat dimonitoring dan diatasi dengan cepat, mudah, dan efisien.

3. Rani Mita Sari (2016) Klasifikasi Kesehatan Bank Menggunakan Sistem Fuzzy Sugeno Order Nol Yang Diimplementasikan Dengan Graphical User Interface (GUI) [10]. Penelitian ini bertujuan membentuk dan mengetahui keakuratan sistem fuzzy Sugeno order nol dalam penilaian tingkat kesehatan bank di Indonesia. Proses pertama adalah menentukan hasil penilaian tingkat kesehatan bank dengan menggunakan metode RGEC. Proses inferensi fuzzy dengan metode fuzzy Sugeno orde nol dan metode weight average pada proses defuzzifikasi. Sistem fuzzy. Yang telah terbentuk diimplementasikan kedalam GUI (Graphical User Interface). Tingkat akurasi yang didapatkan menggunakan metode fuzzy Sugeno pada data latih tahun 2011, 2012, 2013 secara berturut adalah 95.4\%,97.7\%, dan 95.4\%. sedangkan keakuraan pada data testing pada tahun yang sama adalah $100 \%$. Hasil akurasi menunjukan bahwa sistem fuzzy sugeno baik digunakan sebagai penilaian kesehatan bank. 
4. Ari Andini (2018) Sistem pendukung keputusan pemilihan mekanik sepeda motor Yamaha Alfacorfii dengan metode multi objective optimaztion on the basis of ratio analysis (MOORA) [11]. Penelitian ini dapat ddapat dianalaisa bahwa untuk mementukan pemilihan mekanik terbaik bukan hnya dari kriteria keahlian, tetapi diperlukan keriteria yang lain seperti Pendidikan disiplin dan masa kerja. Kedua Pemilihan mekanik terbaik ini menggunakan MOORA yang menghitung bobot nilai dari seriap kriteria dan alternative yang ada dan yang erakhir penentuan mekananik yang terbaik ditentukan dari hasil perankingan yang terbaik dan dipertimbangkan oleh pengambil keputusan.

\section{RESEARCH METHOD}

\section{A. Penentuan Jawaban Metode Fuzzy}

Dalam melakukan implementasi logikia fuzzy, menentukan kriteria yang akan diolah. Setelah melakukan studi pustaka, terbangun 3 variabel penentu dan 1 variabel yang akan menjadi keluarannya. Tiga variable penentu diatanranya jumlah hari (setelah service telah dilakukan atau motor baru keluar), Kilometer tempuh (kilometer saat ini dikurangi setelah service terakhir), dan jenis motor. Keluaran atau output dari fuzzy sendiri berupa variable siap service.

TABEL I

VARIABEL INPUT DAN OUTPUT

\begin{tabular}{|c|c|}
\hline Variabel Input & Variabel Output \\
\hline Jumlah Hari, Kilometer Tempuh, Jenis Motor & Siap Service \\
\hline
\end{tabular}

\section{B. Fuzzifikasi}

Fuzzifikasi merupakan proses konversi nilai-nilai kebenaran yang bersifat pasti (crisp input), yang digunakan sebagai inputan, menjadi bentuk fuzzyinput, yang berupa nilai linguistik yang semantiknya ditentukan berdasarkan fungsi keanggotaan.

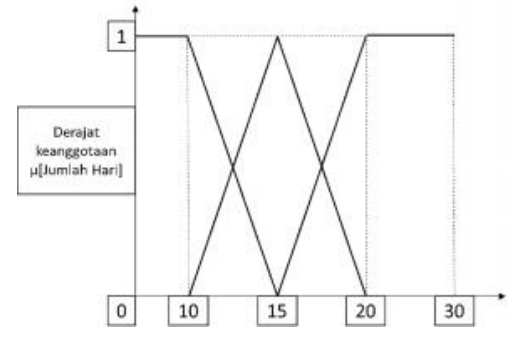

Gambar 1. Grafik fungsi keanggotaan Jumlah Hari

a. Representasi fuzzy jumlah hari sedikit

$$
\mu[\text { sedikit }]=\left\{\begin{aligned}
0, & x \geq 15 \\
\frac{20-x}{20-10}, & 10<x>15 \\
1, & x \leq 10
\end{aligned}\right.
$$

b. Representasi fuzzy jumlah hari sedang 


$$
\mu[\text { sedang }]=\left\{\begin{array}{cl}
0, & x \leq 10 \text { atau } x \geq 20 \\
\frac{x-10}{15-10}, & 10<x>15 \\
\frac{20-x}{20-15}, & 15<x>20 \\
1, & x=12.5
\end{array}\right.
$$

c. Representasi fuzzy jumlah hari tinggi

$$
\mu[\text { tinggi }]=\left\{\begin{aligned}
\frac{x-15^{1},}{20-15^{\prime}}, & x \geq 20 \\
0, & x \leq 15
\end{aligned}\right.
$$

\section{Pembentukan Aturan Dasar}

Setelah mendapatkan variabel yang akan digunakan, terbentuklah aturan-aturan yang menjadipenentu keluaran dari fuzifikasi.

TABEL II

\begin{tabular}{|c|c|}
\hline No & Rules \\
\hline 1 & $\begin{array}{l}\text { If Jumlah Hari Sedikit AND Kilometer } \\
\text { Tempuh Sedikit AND Jenis Motor } \\
\text { Rendah THEN Tidak Siap }\end{array}$ \\
\hline 2 & $\begin{array}{l}\text { If Jumlah Hari Sedikit AND Kilometer } \\
\text { Tempuh Sedikit AND Jenis Motor } \\
\text { Sedang THEN Tidak Siap }\end{array}$ \\
\hline 3 & $\begin{array}{l}\text { If Jumlah Hari Sedikit AND Kilometer } \\
\text { Tempuh Sedikit AND Jenis Motor } \\
\text { Tinggi THEN Tidak Siap }\end{array}$ \\
\hline$\ldots$ & $\ldots$ \\
\hline 27 & $\begin{array}{l}\text { If Jumlah Hari Sedang AND Kilometer } \\
\text { Tempuh Sedikit AND Jenis Motor } \\
\text { TinggiTHEN Tidak Siap }\end{array}$ \\
\hline
\end{tabular}

RULES

\section{Komposisi Aturan}

Tahap ini setelah dibentuk aturan dasar, maka akan dilakukan komposisi aturan untuk mendapatkan bobot dari aturan dasar menggunakan fungsi implikasi MIN. Rumus komposisi aturan:

$$
a-\text { predikat } 1=\text { MIN }(\mu \mathrm{JumlahHari} \cap \mu \text { KilometerTempuh } \cap \mu \mathrm{J} \text { enisMotor })
$$

\section{E. Defuzzifikasi}

SetelahSetelah dilakukan komposisi aturan, maka dilakukan defuzzifikasi dengan menggunakan weighted average. Defuzzifikasi di dalam aplikasi Motor Life ini digunakan untuk mencari bobot terakhir dari setiap kriteria tersebut. Untu mencari bobot terakhir digunakan rumus defuzifikasi dibawah ini.

$$
z=\frac{a-\text { predikat } 1 * z 1+a-\text { predikatn } * z n}{a-\text { predikat } 1+a-\text { predikat } n}
$$

\section{F. Output}

Dapat dianalisis bahwa hasil dari weighted average adalah bobot terakhir yang digunakan untuk dijadikan penentu kesiapan motor. Dalam implementasi ini dilakukan pengecekan terhadap nilai defuzzifikasinya. 
Pengecekan dilakukan dengan mengabil nilai tengah kesiapan service antara 0 dan 100 yakni 50 sehingga didapatkan bahwa jika nilai defuzzifikasi lebih dari 50 maka akan mengeluarkan hasil motor siap diservice. Sedangkan sebaliknya untuk tidak siap service atau motor masih dalam kondisi sehat apabila nilai defuzzifikasi kurang dari 50.

\section{RESULTS AND DISCUSSION}

\section{A. Blackbox Testing}

Berdasarkan rencana pengujian yang telah disusun, maka dapat dilakukan pengujian setiap perangkat smartphone Android.HP Oppo F7.

Berikut hasil pengujian black box pada perangkat Oppo F7yang dapat dilihat pada Tabel 3.

TABEL III

Hasil Pengujian Black Box Pada PerangKat Oppo F7

\begin{tabular}{|c|c|c|}
\hline No & Detail Pengujian & Hasil Pengujian \\
\hline 1 & Menampilkan Halaman Utama & Berhasil \\
\hline 2 & Masuk Kedalam Input Data & Berhasil \\
\hline 3 & Dapat Menerima Notifikasi & Berhasil \\
\hline 4 & Dapat Menjalankan Metode Fuzzy & Berhasil \\
\hline 5 & Dapat Mengesave Data User & Berhasil \\
\hline
\end{tabular}

\section{B. Hasil Pengujian Metode Fuzzy}

Perhitungan akurasi dilakukan dengan cara menguji sistem dengan melakukan sample percobaan dengan memasukan 30 data pengujian dari masing-masing jenis motor, Hasil dari pengujian terdapat pada Tabel 4dengan menggunakan metode perhitungan manual.

TABEL IV

HASIL PENGUJIAN PERHITUNGAN MANUAL

\begin{tabular}{|c|c|c|c|c|c|c|}
\hline $\begin{array}{c}\text { Percobaan } \\
\text { ke- }\end{array}$ & $\begin{array}{c}\text { Kilometer } \\
\text { Awal }\end{array}$ & $\begin{array}{c}\text { Kilometer } \\
\text { Akhir }\end{array}$ & $\begin{array}{c}\text { Tanggal } \\
\text { Terakhir } \\
\text { service }\end{array}$ & $\begin{array}{l}\text { Tanggal } \\
\text { Service }\end{array}$ & $\begin{array}{l}\text { Jenis } \\
\text { Motor }\end{array}$ & Hasil \\
\hline 1 & 2,400 & 5,000 & 1-Mar-19 & 2-Apr-19 & Bebek & Siap Service \\
\hline 2 & 1,500 & 2,500 & 2-Mar-19 & 2-Apr-19 & Bebek & $\begin{array}{c}\text { Tidak Siap } \\
\text { Service }\end{array}$ \\
\hline 3 & 200 & 1,200 & 3-Mar-19 & 2-Apr-19 & Bebek & $\begin{array}{c}\text { Tidak Siap } \\
\text { Service }\end{array}$ \\
\hline 4 & 450 & 1,500 & 4-Mar-19 & 2-Apr-19 & Bebek & $\begin{array}{c}\text { Tidak Siap } \\
\text { Service }\end{array}$ \\
\hline$\ldots$ & $\ldots$ & $\ldots$ & $\ldots$ & $\ldots$ & $\ldots$ & $\ldots$ \\
\hline$\ldots$ & $\ldots$ & $\ldots$ & $\ldots$ & $\ldots$ & $\ldots$ & $\ldots$ \\
\hline 30 & 123,211 & 125,675 & 30-Mar-19 & 4-Apr-19 & Sport & Siap Service \\
\hline
\end{tabular}

Komposisi aturan dilakukan sampai dengan 27 aturan dan didapatkan hasil. Setelah dilakukan komposisi aturan, selanjutnya proses defuzzifikasi dengan menghitung weighted average untuk mengetahui bobot yang akan dikeluarkan.

$$
z=\frac{(0 * 0)+(0 * 0)+(0 * 0)+\cdots+(0 * 100)}{0+0+0+\cdots+0}=100 / 1=100
$$




\section{Pengujian Sistem Dengan Metode Kuesioner}

Hasil rata-rata kuesioner Aplikasi Motor Life yaitu 87,85\% setuju terhadap pengaruh dari aplikasi Motor Life. Berikut hasil dan evaluasi kuesioner dari pengguna aplikasi Motor life ini.Untuk mengecek validitas kuisioner yang telah diisi, menggunakan SPSS untuk menghitung Validitas yang ada.

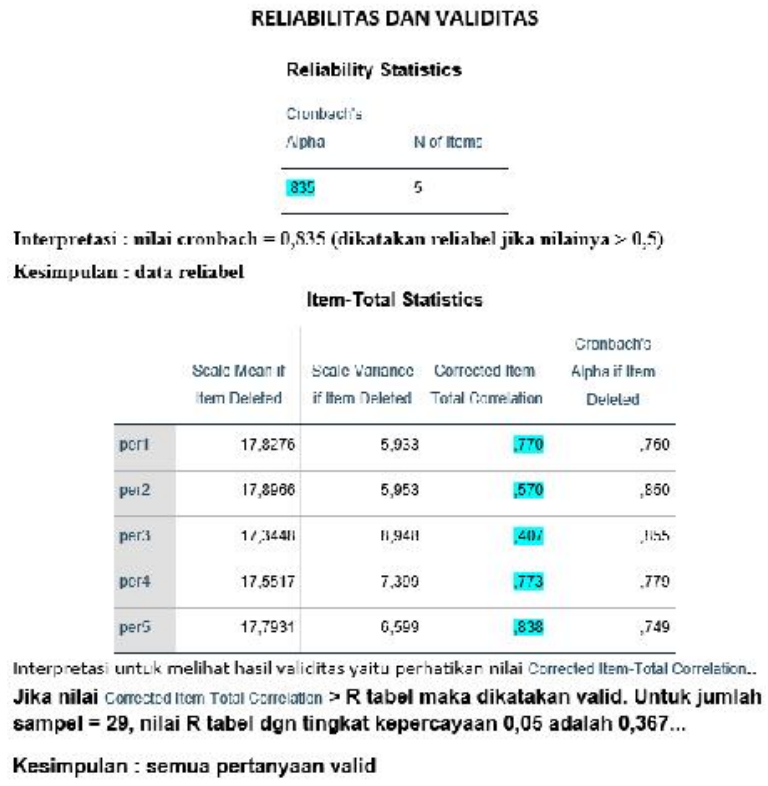

Gambar 2. Hasil Pengujian Kuesioner

Dapat dianalisis bahwa validitas dari setiap kuisioner telah tervalidasi dengan baik.

\section{CONCLUSION}

Berdasarkan pengujian manual dan pengujian melalui system yakni 16 siap service dan 14 tidak siap service. Presentase keakuratan system dengan perhitungan manual 100\% sama dengan perhitngan system. Prensentasi pengaruh terhadap perawatan motor adalah $88.27 \%$ setuju terhadap pembuatan aplikasi ini untuk perawatan motor terhadap kecelakaan motor.

\section{ACKNOWLEDGMENT}

Penulis mengucapkan terima kasih kepada pembimbing yang telah menuntun dan membimbing penelitian ini hingga selesai. 


\section{REFERENCES}

[1] B. P. Statistik, "Produksi Kendaraan Bermotor," Jakarta, 2016.

[2] Katadata, “Sepanjang 2017 Terjadi 98 Ribu Kali Kecelakaan Lalu Lintas,” Badan Pus. Stat., p. 1, 2018.

[3] L. C. de Barros, Laéci Bassanezi, R. C. Bassanezi, and W. A. Lodwick, A First Course in Fuzzy Logic, Fuzzy Dynamical Systems, and Biomathematics, vol. 347, no. 0. Berlin, Heidelberg: Springer Berlin Heidelberg, 2017.

[4] K. Honjo, S. E. Mauthner, Y. Wang, J. H. P. Skene, and W. D. Tracey, "Nociceptor-Enriched Genes Required for Normal Thermal Nociception," Cell Rep., vol. 16, no. 2, pp. 295-303, Jul. 2016.

[5] M. Irfan, L. P. Ayuningtias, and J. Jumadi, "Analisa Perbandingan Logic Fuzzy Metode Tsukamoto, Sugeno, Dan Mamdani (Studi Kasus: Prediksi Jumlah Pendaftar Mahasiswa Baru Fakultas Sains Dan Teknologi Uin Sunan Gunung Djati Bandung),” Tek. Inform., vol. 10, no. 1, 2018.

[6] F. Ardhy and D. Marisa Efendi, "PERBANDINGAN METODE FUZZY INFERENSI TSUKAMOTO DAN SUGENO UNTUK MEMPREDIKSI PEMESANAN ROTI JORDAN,” TEKNO KOMPAK, vol. 12, no. 2, pp. 45-50, 2018.

[7] A. Triyanto, "Studi Perbandingan Metode Fuzzy Tsukamoto Dan Fuzzy Mamdani Untuk Seleksi Pegawai Teladan,” pp. 1-8, 2014.

[8] M. Rofiq, "Perancangan Manajemen Bandwidth Internet," J. Ilm. Teknol. dan Inf. ASIA, vol. 7, no. 1, pp. 1-15, 2013.

[9] D. Hervita, A. Taqwa, and M. M. Rose, "Sistem Monitoring Level Air Radiator Kendaraan Dengan Metode Fuzzy," J. Elektro dan Telekomun. Terap., vol. 4, no. 1, p. 485, 2017.

[10] R. Mita Sari and A. Maman Abadi, "Sugeno Order Nol Yang Diimplementasikan Dengan Graphical User Interface (Gui ),” no. 10, pp. 1-9, 2016.

[11] A. Andini, G. A. Lestari, I. Mawaddah, A. S. Ahmar, and Khasanah, "Penerapan Sistem Pendukung Keputusan Pemilihan Ban Sepeda Motor Honda Dengan Metode Multi Objective Optimization on The Basic of Ratio Analysis (MOORA )," J. Ris. Komput., vol. 5, no. 1, pp. 29-35, 2018.

[12] S. Kusumadewi, Artificial Intelligence (Teknik dan Aplikasinya), I. Yogyakarta: Graha Ilmu, 2003.

[13] Android Open Source Project, “Android Overview | Open Handset Alliance.” 2013.

[14] Astra Honda Cengkareng, “Mengapa Anda Harus Mengganti Oli Motor Anda secara Rutin?,” 2015. [Online]. Available: https://www.hondacengkareng.com/mengapa-anda-harus-mengganti-oli-motor-anda-secara-rutin/. [Diakses: 10-Feb-2019]. 